症 例 報 告

\title{
中等度認知症患者に飴を用いる口腔機能リハビリテーションを行った一症例
}

\author{
山脇加奈子 ${ }^{\mathrm{a}}$, 吉川峰加 ${ }^{\mathrm{b}}$, 津賀一弘 ${ }^{\mathrm{b}}$, 久保隆靖 ${ }^{\mathrm{b}}$, 田地 豪 $^{\mathrm{c}}$, 赤川安正 ${ }^{\mathrm{d}}$
}

\section{Functional Oral Rehabilitation using Lollipop Candy for a Dysphagia Patient with Moderate Dementia}

\author{
Kanako Yamawaki, DDS , Mineka Yoshikawa, DDS, $\mathrm{PhD}^{\mathrm{b}}$, Kazuhiro Tsuga, DDS, $\mathrm{PhD}^{\mathrm{b}}$, \\ Takayasu Kubo, DDS, $\mathrm{PhD}^{\mathrm{b}}$, Tsuyoshi Taji, DDS, $\mathrm{PhD}^{\mathrm{c}}$ and Yasumasa Akagawa, DDS, $\mathrm{PhD}^{\mathrm{d}}$
}

\begin{abstract}
抄 録
症例の概要：患者は 73 歳男性で脳血管性認知症を有しており，認知症病棟に入院中である。唾液や食物 を飲み込みにくいという主訴の下，摂食観察を行ったところ多量の口腔内食物残留および喫食率の低下を 認めた。 また，與下造影検査（Videofluoroscopic examination of swallowing: VF) では，舌㩁送運動 の不良，嚥下反射の惹起遅延，ならびに口蓋から咽頭部にかけての食物残留を認めた。そこで，従来から の口腔機能リハビリテーションに加え，飴を舐める機能を応用したリハビリテーションを 6 カ月間行い, 訓練介入前後および介入期間中の燕下機能, 口腔機能, 口腔内環境, 体重および摂食状況を観察したとこ ろ, 舌搾送運動の改善, 最大舌圧值, 体重, 喫食率の増加, 口腔内の食物残留量や細菌数の減少を認めた。 考察 : 中等度認知症患者に対し, 従来のリハビリテーションに加えて, 複雑な指示理解を必要としない飴 を舐めるリハビリテーションを継続することにより, 口腔内および口腔周囲筋の廃用防止と口腔内環境の 改善につながつたものと考えられた。

結論 $: 6$ 力月間の本口腔機能リハビリテーションにより, 口腔の機能と環境に改善を認めたことより, 中 等度認知症患者において，飴を用いたリハビリテーションが有効である可能性が示唆された。
\end{abstract}

和文キーワード

認知症, 舐摂機能, 飴, 口腔内細菌数, 口腔機能

\section{I. 緒 言}

近年，認知症高齢者および摂食嚥下障害患者の増加に 伴い，種々の口腔機能リハビリテーションが行われてい る る $^{1,2)}$ 認知症高齢者に対しては主に姿勢や食事調整など の環境設定に関する改善策 ${ }^{3)}$ が報告されているものの, 口腔機能の低下に対する舌抵抗訓練や構音訓練について は術者の指示に対する患者の理解が難しいことより, 積 極的なリハビリテーション, 特に間接法の筋機能訓練の
実施が困難な状況である ${ }^{4)}$. しかし，食物を舐めて摂取 する訓練であれば可能ではないかと考え, 今回, 酀下障 害を有する脳血管性認知症患者に対して，従来からのリ ハビリテーションに加え, 簡易的で安全な棒付き飴を使 用し，リハビリテーションを行った。本論文では，土岡 $ら^{5)}$ が呼称したように, 棒付き飴を舐めて摂取する機能 を「舐摂機能」, またその訓練を「舐摂機能訓練」と定義 し, 訓練介入前後および介入期間中の燕下機能, 口腔機能, 口腔内環境，体重および摂食状況の変化をとらえること

a 医療法人ピーアイエー ナカムラ病院

${ }^{\mathrm{b}}$ 広島大学大学院医歯薬保健学研究院応用生命科学部門先端歯科補綴学

c 広島大学大学院医歯薬保健学研究院統合健康科学部門口腔生物工学分野

d 奥羽大学

${ }^{a}$ Nakamura Geriatric Hospital

${ }^{\mathrm{b}}$ Department of Advanced Prosthodontics, Applied Life Sciences, Institute of Biomedical and Health Sciences, Hiroshima University

${ }^{\mathrm{c}}$ Department of Oral Biology and Engineering, Integrated Health Sciences, Institute of Biomedical and Health Sciences, Hiroshima University

¿ Ohu University

受付: 2014 年 7 月 22 日/受理 : 2015 年 1 月 5 日

Received on July 22, 2014/Accpted on January 5, 2015 
により, 患者の曣下障害の改善と新しいリハビリテーショ ンの可能性を明らかにすることを試みた。なお，患者家 族の同意の下，本症例を報告する。

\section{II. 症例の概要}

患者 : 73 歳, 男性.

初診日（歯科）：2012 年 7 月.

主訴：食事が飲み込みにくい.

既往歴：2007 年に脳梗塞を発症した。後遺症として 右片麻痺，言語障害，脳血管性認知症を認めた。2011 年 4 月に，アダムストークス発作を起こし，冠動脈形成 術（ステント留置）を施行した。その後，老人保健施設 にて過ごしていたが，次第に不穏，暴言，暴力，危険行 為などの認知症による周辺症状を頻回に認め, 2011 年 6 月に当院認知症医療病棟に入院した。その他の基礎疾患 は，糖尿病，高血圧，高脂血症であった。

現病歴：2012 年 7 月に患者より飲み込みにくいと訴 えがあり，病棟スタッフより飲み込みの検査および義歯 の適合の精査依頼があり，当院歯科を受診した。

現症ならびに検査所見 :

摂食状況は，自力での経口摂取で喫食率は 3 割であっ た。平生は食事介助を行い 40 分で 7 割を摂取し，藤島 グレード ${ }^{6)}$ はLv.8であった。食事形態は主食がパン (牛 乳で浸したもの), 副食が有形おかずであり, 多量の口腔 内食物残留を認めた。スクリーニング検査 ${ }^{6)} に て 反$ 復唾 液嚥下テスト（RSST）は 0 回/30 秒，改訂水飲みテス 卜は 4 点（嚥下あり，むせなし，呼吸変化・湿性嗄声な し）であった，構音器官の検査 ${ }^{7}$ より，挺舌は下唇を超 えない程度で，偏位は認められなかった。発声に関して は声量の低下と不明瞭な発語を認めた。また精査のため に行った VF 検査では，明らかな䛊嚥を認めなかったも のの, 舌機能低下に伴う食塊形成不全や舌㩁送運動不良, 嚥下反射の惹起遅延を認めた。また，口蓋から咽頭（喉 頭蓋谷·梨状陥凹）にかけての食物残留が顕著であった。

患者は上顎部分床義歯 762|4-7を装着しており，適 合・咬合ともに良好で咀嚼運動に問題はなかった。残存 歯 $5431|23 ， \overline{5-1}| 2-7$ は中等度歯周炎で, 病棟スタッ フによる口腔ケアを毎食後行い，歯科による専門的口腔 ケアを月 1 回行っていた。

認知機能は改訂長谷川式簡易知能評価スケール (HDS-R) が 14/30, 認知機能検査 (Mini Mental State Examination）が 17/30 で中等度の認知症であった。

内服薬剤は糖尿病治療薬スルフォニル尿素系（グリメ ピリド)，抗血小板薬 (アスピリン)，抗血小板薬（シロ スタゾール)，塩類下剤（酸化マグネシウム），排尿障害 治療薬 (タムスロシン塩酸塩)，コリンエステラーゼ阻害 薬 (ジスチグミン臭化物), プロトンポンプ阻害薬 (ラン ソプラゾール)，カリウム製剤（L- アスパラギン酸カリ ウム) であった。
診断：脳梗塞による口腔期・咽頭期の摂食嚥下障害

\section{III．治療内容と経過}

$\mathrm{VF}$ 検査で認めた所見に対して，まずは従来の訓練内 容でプログラムを立案した。藤島ら ${ }^{8)}$ の訓練法より，嚥 下に関連する口腔周囲および頸部筋群のリラクゼーショ ンおよび覚醒の向上を図るため (1) 頸部可動域訓練と (2) 舌の運動を行った，舌㩁送運動不良，嚥下反射の惹起遅 延に対しては，舌および舌骨上筋群の筋力増強，口腔か ら咽頭への陽圧の改善に加えて，燕下反射の促通を目的 として（3）舌抵抗訓練を実施するとともに, 唇・顎・舌尖・ 舌背の運動領域の拡大および声門閉鎖強化 ${ }^{7)}$ のために (4) 構音訓練を行った。また，認知症に伴い指示理解が不十 分で，訓練が充分に行えない場合も考慮し，口腔周囲筋 および舌運動として棒付き飴を舐める（5）舐摂機能訓 練を追加した。本訓練は飴を使用することで舌苔の除去 ${ }^{9}$ や口腔内湿潤 ${ }^{10)}$ などの口腔内環境の改善も目的とした。

1. 訓練内容

2012 年 9 月から 6 力月間，以下の（1）〜（5）を週 3 回 ${ }^{11}$, 同一の歯科医師が実施した

（1）頸部可動域訓練 上下左右運動 各 10 秒固定，頸 部回旋

（2）舌の運動舌突出および左右運動 各 10 回

（3）舌抵抗訓練 舌圧子にて前方・上方・側方から 負荷をかけ押し返す運動 各 10 秒

（4）構音訓練 $/ \mathrm{pa} / \cdot / \mathrm{ta} / \cdot / \mathrm{ka} /$ 各 10 回大き く速く発音

（5）舐㨟機能訓練 15 分間飴を舐め続ける（図 1) $\left(\mathrm{H}+\mathrm{B}\right.$ 棒付きキャンディ ${ }^{\circledR} ，($ 株 $\mathrm{H}+\mathrm{B}$ ，岡山）（図 2) 訓練に使用した飴は約 $10 \mathrm{~g}$ でマルチトールおよびトレ ハロースを成分とし，糖尿病患者でも摂取できるよう開 発されたものであった。土岡ら ${ }^{5)}$ が報告する要介護高齢 者男性の舐摂機能検査值 $0.83 \pm 0.27 \mathrm{~g} / \mathrm{min}$ を参考にし, 飴を舐めきるために必要な時間として 15 分を設けた。

\section{2. 評価方法}

嚥下機能に関しては藤島ら ${ }^{6)}$ の評価項目から当院で実 施可能な RSST，改訂水飲みテストおよび VF 検査を，口 腔機能に関しては舌の筋力と運動性を評価するために最 大舌圧 ${ }^{11}$ 測定とオーラルディアドコキネシス ${ }^{8)}$ を選択し た. RSST 扮よび改訂水飲みテストは訓練介入開始から 2 力月毎, VF 検査は患者の被曝や検査室への移動の負担 を考慮し, 3 力月毎に行った。 最大舌压は 1 力月毎, オー ラルディアドコキネシスを 2 カ月毎に測定した。最大舌 圧の測定には舌圧測定器 (JMS 舌圧測定器 ${ }^{\circledR}, J M S$, 広島) を用い，オーラルディアドコキネシスには 口腔機能測 定器（健口くん ${ }^{\circledR}$, 竹井機器工業, 新潟) を用いて $/ \mathrm{pa} /$, /ta/ および / ka/の 1 秒あたりの発音回数を測定した.

舐提機能の評価としては，15 分間の飴の減少量を土岡 

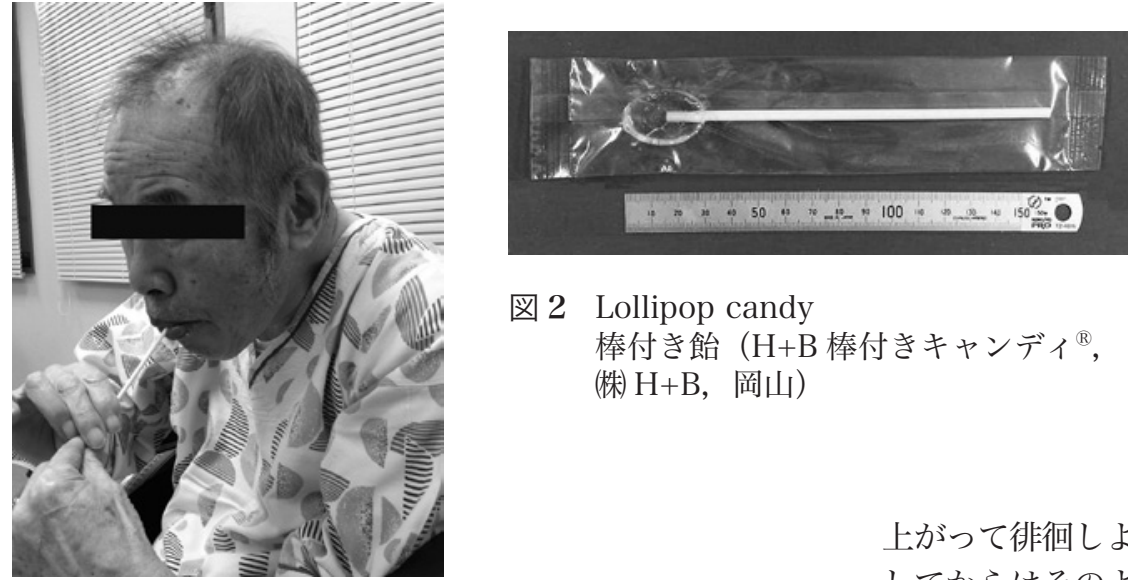

図 2 Lollipop candy 棒付き飴 $\left(\mathrm{H}+\mathrm{B}\right.$ 棒付きキャンディ ${ }^{\circledR}$, (株) $\mathrm{H}+\mathrm{B}$ ，岡山）

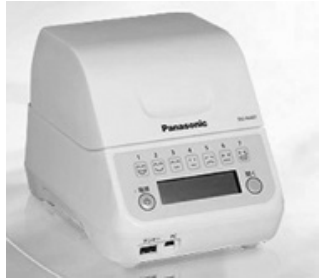

図 3 Oral bacteria detection device 細菌測定器（細菌カウンタ ${ }^{\circledR}$, Panasonic，東京）
図 1 Functional oral rehabilitation sucking lollipop candy 舐摂機能訓練

ら ${ }^{5)}$ の報告に準じて $(\mathrm{g} / \mathrm{min})$ に換算し，1 カ月毎に測定 した。口腔内環境の評価としては，口腔内細菌数を 2 力 月毎に測定した。測定には細菌測定器（細菌カウンタ ${ }^{\circledR}$, Panasonic, 東京) (図 3) を用い ${ }^{12}$, 舌背部中央 $1 \mathrm{~cm}$ の 距離を滅菌綿棒を 3 往復させ擦過し, 細菌を採取測定し た. 15 時の間食前に 3 回測定し,最高值を測定值とした。

また，体重，食事時間および喫食率を 2 力月毎に測定 した。なお，Robbins ら ${ }^{13)}$ が 2 力月間の舌運動訓練での 効果を報告していることに準じ，評価項目の測定期間は 2 力月毎としているが, 本研究では最大舌圧值と飴の減 少量を 1 力月毎に行った.

\section{3. 経過}

訓練期間中，食事形態の変更なく藤島グレードは Lv.8 であった。（1）頸部可動域訓練はほぼすべての日に行え たが，指示理解が不十分な日は，歯科医師が大きな声で 話しかけ手本を見せ，徒手的に補助しながら行った。(2) 舌の運動は指示理解が可能な日は行うことができたが, 突 出は常に下唇を超えず，上下は口唇に触れる, 左右は口角 を触れる程度であった。覚醒不良の日は舌を動かすことす ら不可能であった。 なお患者は, 訓練介入 3 力月頃に他 患者への暴力行為を認めたため, 抗精神薬リスペリドン ${ }^{14)}$ $1 \mathrm{mg} 2.5$ 錠/ 日の内服が開始となり，同時期の覚醒は著 しく不良であった。（3）舌抵抗訓練は歯科医師が舌圧子 で負荷をかけているものの, 患者の舌の抵抗力は弱く, 指 示理解が不十分な日は，抵抗を感じない事もあった。(4) 構音訓練は歯科医師がまず手本を見せ, 行ったが, 常に声 量は小さく, /pa/・/ta/・/ka/の発語は不明瞭であった. 特に $/ \mathrm{ka} /$ ははっきりと連続して発音することが困難な様 子であった。覚醒不良の日は閉眼したまま行うなど, 意欲 の低下を認めた。(5)舐摂機能訓練は訓練期間中ほぼすべ て日に，患者が棒付き飴を持ち，舌で転がしながら 15 分 間舐めることが可能であった。 介入開始から 1 力月の間 は集中力が続かず，途中で飴を加えたまま横たわる，立ち
上がって徘䧃しようとすることもあったが, 1 力月を経過 してからはそのような行動は認められなかった。覚醒不良 の日は，飴を舐めながら，途中で閉眼することもあった。 月に 1 回程度, 訓練中にムセを認め中断する日があり, 特 にリスペリドン $1 \mathrm{mg} 2.5$ 錠/日を内服している時期は流 延が著しく，ムセによる中断の頻度は週に 1 回に増えた。 内服量が $1 \mathrm{mg} 1$ 錠/日に減量してからは，中断すること はなかった。なお， 6 力月後頃に患者の帰宅願望か強くな り, 訓練後に病棟から脱出しようとするなど精神状態が悪 化し, 訓練継続が困難となったため, この時点で介入を終 了した。

評価項目に関しては次のような結果であった。 RSST は介入開始時に 0 回/30 秒で, 2 力月に 1 回/30 秒に増 加したが、以後はすべて 0 回/30 秒であった。改訂水飲 みテストは介入開始時から終了後まですべて 4 点（嚥下 あり，むせなし，呼吸変化・湿性嗄声なし）であった。 $\mathrm{VF}$ 検査では介入開始時から 3 力月後には舌搾送運動の 改善を認め, 讌下 1 回あたりの口腔内食物残留量も介 入時と比較して減少していたが, 6 力月後には舌搾送運 動と與下 1 回あたりの口腔内残留量が介入開始時と同程 度になった。最大舌圧值は介入開始時から 2 力月後に, $5.7 \mathrm{kPa}$ から $11.4 \mathrm{kPa}$ へ明らかな増加を認め, 2 力月 から 4 力月にかけては $11.4 \mathrm{kPa}$ からほぼ変化はなかっ た. 5 力月目には $16.3 \mathrm{kPa}$ とさらなる増加を認めたが, 6 力月の介入終了時には $11.6 \mathrm{kPa}$ に隇少した（表 1$)$.

オーラルディアドコキネシスでは $/ \mathrm{pa} /$ 及び / $\mathrm{ka} /$ が介 入開始時から 4 力月後にはそれぞれ明らかな増加を認め た (/pa/2.8回/秒から 4.6 回/秒, /ta/3.6 回/秒から 4.4 回/秒) が, $/ \mathrm{ta} /$ は介入開始時の 3.4 回/秒から介入 終了時までほぼ変化を認めなかった。飴の減少量は介入 開始時から 2 力月後までは $0.29 \mathrm{~g} / \mathrm{min}$ から $0.41 \mathrm{~g} / \mathrm{min}$ へと緩やかに増加したが, 3 力月から 4 力月にかけて, $0.33 \mathrm{~g} / \mathrm{min}$ から $0.15 \mathrm{~g} / \mathrm{min}$ へと明らかな減少を認めた。 その後は介入開始時と同程度まで増加した（表 2 ).

口腔内細菌数は介入開始時から 6 力月後の介入終了時 には 6.92 ( $\log _{10}$ (個), 以下同様) から 6.32 へと明らか な細菌数減少を認め, 介入終了 1,2 力月後にはそれぞ れ 6.68，7.06へと増加を認めた（表 3). 
表 1 Maximum voluntary tongue pressure 最大舌圧值

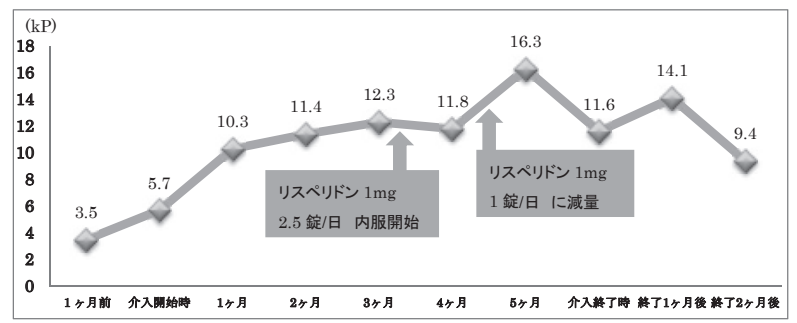

表 2 The number of oral bacteria 口腔内細菌数

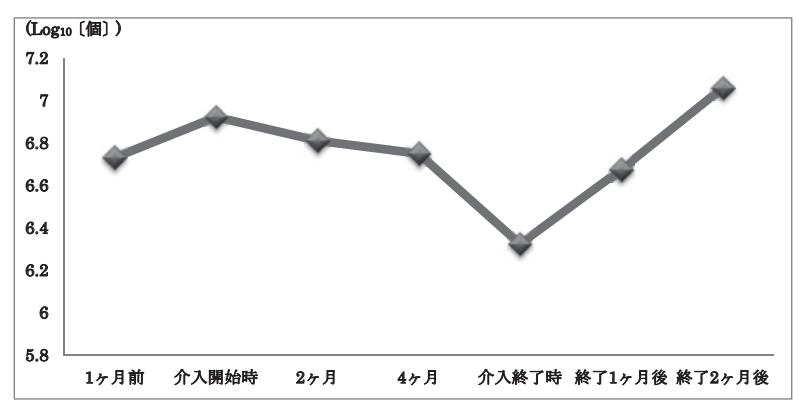

表 3 The quantity of candy loss weight 飴の減少量

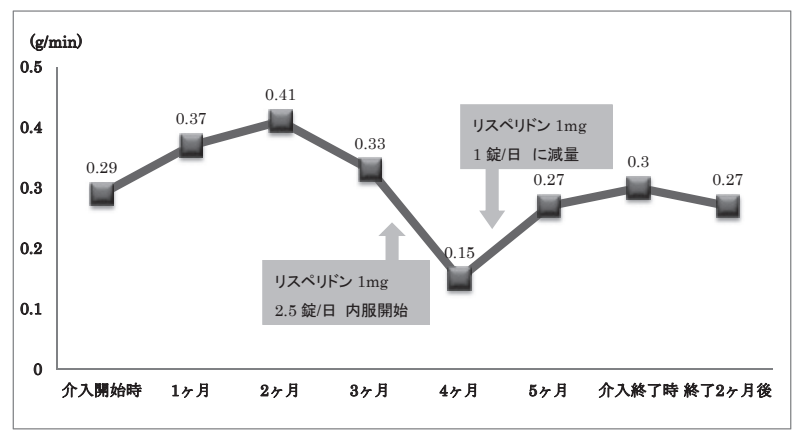

体重は 2 力月後に約 $5 \mathrm{~kg}$ の増加を認め, 介入終了時 まではほぼ変化がなかったが，終了 2 力月後には約 $5 \mathrm{~kg}$ 減少し，開始時の体重に戻った。食事時間および喫食率 は介入開始時に 40 分・70\% で， 2 力月から介入終了ま では 30 分・100\% であったが，終了 2 力月後には 40 分・ $90 \%$ と推移した。

\section{IV. 考 察}

随意での酀下機能を評価する RSST は訓練実施中に大 きな変化を認めなかった。この項目は指示理解が必要で あることから、理解が不十分で唾液を嚥下できなかった のか訓練が奏功しなかったかの判断は不可能であった。 改訂水飲みテストでは，すべて 4 点で高得点のため嚥下 機能を維持できていた可能性があった. VF検査において, 訓練介入開始から 3 力月後に舌搾送運動の改善および曖 下 1 回あたりの口腔内食物残留量の減少を認めたことは,
舌の筋力増強と運動性の向上が得られた可能性が高く, 訓練による効果と考えられた。しかしながら，6力月後 に開始時と同程度まで機能が戻ったことは，同時期に患 者の精神状態が悪化したことが原因と考えられた。最大 舌圧值が 5 力月から 6 力月にかけて減少していたことも, 同じ理由が考えられた。

オーラルディアドコキネシスの基準值は原ら ${ }^{15)}$ の報告 により $65 \sim 74$ 歳群で/pa/が 3.8 回/秒, / ta/ が 4.1 回/秒，/ka/ が 3.7 回/秒である。本訓練の介入開始時 に患者は /pa/ が 2.8 回/秒, /ta/ が 3.6 回/秒，/ka/ が 3.6 回/秒を示したことより / pa/・/ta/ の機能がやや低 かったといえる. 訓練介入開始から 4 力月後に $/ \mathrm{pa} /$ およ び/ka/ は明らかな増加を認め, 訓練の効果とも考えられ たが，発語は依然として不明瞭であり，声量が小さく測 定の正確さにも欠けたため, 詳細な判断は困難であった。

Utanohara $^{16)}$ の報告より健常高齢者 70 歳における最 大舌圧の基準値は $31.9 \pm 8.9 \mathrm{kPa}$ であり，介入開始時に $5.7 \mathrm{kPa}$ を示した患者は著しく舌の筋力が低下していた といえる. 2 力月後に $11.4 \mathrm{kPa}$ まで増加していることよ り，訓練が奏功したと考元られるが，以後 4 力月目まで 横ばいであった原因は 3 力月過ぎ頃に内服開始となった リスペリドンの影響である可能性が考えられる。リスぺ リドンは，セロトニン・ドパミン遮断薬で統合失調症に 用いることが一般的であるが，認知症における幻覚・妄 想，強迫性障害，興奮などの症状にも鎮静作用があり処 方される。同時に副作用として錐体外路症状，流延，眠 気, 口渴, 倦急感などが挙げられている ${ }^{14)}$. 本症例にお いては患者の暴力行為に対する処方であったが，副作用 の眠気や倦㤐感より覚醒不良や訓練意欲低下といった症 状が現れ，結果として（2）舌の運動，(3) 舌抵抗訓練, （4）構音訓練が充分に行えず，舌の筋力向上が停滞した と推察した。 リスペリドン減量時の 5 力月後には再び $16.3 \mathrm{kPa}$ まで増加していたことから，同薬剤の影響は否 定できなかった。加えて, 内服中も舌圧の維持はできて いたとも捉えられた。

飴の減少量に関しては土岡ら ${ }^{5)}$ の報告より要介護高齢 者男性の舐摂機能基準值が $0.83 \pm 0.27 \mathrm{~g} / \mathrm{min}$ であるこ とから，患者は開始時に $0.29 \mathrm{~g} / \mathrm{min}$ を示しており，舐 摂機能も低い状態であった， 2 力月後には訓練が奏功し $0.41 \mathrm{~g} / \mathrm{min}$ まで増加，4 カ月後にはリスペリドンが影響 し一旦 $0.15 \mathrm{~g} / \mathrm{min}$ まで減少した。覚醒不良によって飴 を舐める動きが鈍くなったことも考えられるが、唾液流 量との関連も考慮する必要があげられた ${ }^{5)}$. 同薬剤の副 作用には口渴も言われており，唾液流量の減少が飴を舐 める量を減少させたことも考えられた。実際には，薬剤 服用中は流延が著しく飴を舐めながら口唇から唾液がこ ぼれ落ちている状態であったため, 唾液流量と飴の減少 量の関連性は，この症例においては不明である。

口腔内細菌数が介入 6 力月にかけて明らかに減少した 
という結果については，(2) 舌の運動，(3) 舌抵抗訓練, (4) 構音訓練が十分実施できなかった日も舐摂機能訓練 にて飴を加えて舐めるという動作はできていたことより， それ自体が舌運動や口腔粘膜への刺激となりリスペリド ンの副作用に著しく影響を受けた期間以外は，唾液分泌 が改善され ${ }^{7)}$ ，口腔内湿潤が上昇した ${ }^{10)}$ 状態が継続でき ていた可能性も考えられた。唾液量増加と口腔内細菌数 減少の関連は石川らにより報告されている ${ }^{18)}$. また飴を 舐めることにより舌苔が除去された こととも考えられる.

大屋ら ${ }^{19)}$ の報告によると, 訓練にて体重が増加した症 例もあり, 今回介入開始から 2 力月にかけて患者の体重 が $5 \mathrm{~kg}$ 増加したことは, 食事が十分にできていたことや, 介入終了後に体重が $5 \mathrm{~kg}$ 滅少したことを踏まえると, 少 なからず訓練が奏功した可能性はある。しかし 3 力月以 降はリスペリドンの副作用である体重増加 ${ }^{14)}$ も可能性は 否定できず，明確な判断は困難である.

これらをまとめると, 本症例において得られた結果が 従来の訓練の効果か舐摂機能訓練の効果か明確に判断す ることはできないが，併用して継続することで効果が得 られる項目があった。途中リスペリドンにより影響を受 けた期間があったものの，舌圧が著しく低下することは なく, 服薬を減量したことで再び訓練効果が得られた。 したがって, 指示理解が不十分な認知症患者に対して, 適切な抗精神薬のコントロール下であれば，従来の訓練 に加えて飴を用いるリハビリテーションを行うことは有 効と考えた。

なお，訓練介入終了から 3 力月後，患者への治療介入 が可能な程度まで精神状態が安定したため機能維持・向 上を目的とし訓練の再開を検討したが，体力の低下を考 慮し, 負荷をかけずに口蓋の食物残留を除去する目的で, 舌接触補助床（PAP）の作製を試みた。残留を認めた部 分は $\mathrm{S}$ 状隆起より後方であったため, 同部から義歯後縁 にかけて移行的に約 $8 \mathrm{~mm}$ の厚みを付与した. 8 力月間 ほど装着していたが, 経過の評価過程で全身状態が悪化 し，装着から 1 年後に死亡した。

\section{V. 結 論}

飴を用いる舐摂機能訓練を従来の訓練に加えた 6 カ月 間の口腔機能リハビリテーションでは，抗精神薬リスペ リドンの内服開始及び内服量の増減が，最大舌圧值と飴 の減少量に影響を与えたが, 喫食率, 最大舌圧值は増加 し, 口腔内食物残留量や口腔内細菌数は減少したことか ら，同リハビリテーションが適切な服薬コントロール下 において, 摂食状況を維持し, 口腔機能に加えて口腔内 環境をも改善できる可能性が示唆された。

\section{文献}

1）清水充子、リハビリテーションの実際。苅安 誠, 谷本啓二,

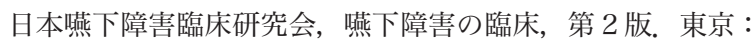

医歯薬出版；2008，163-291。

2）羽飼富士男, 立石雅子. 加齢性変化と摂食・噁燕下障害のリ八 ビリテーション，老年精医誌 $2009 ； 20 ： 1363-1369$.

3）山田律子. 摂食・嘸下障害をもつ認知症の人に対する看護の 実際。老年精医誌 $2009 ; 20: 1377-1386$.

4）野原幹司. 摂食・嚥下リハビリテーション. 山脇正永, 小谷泰子, 認知症患者の摂食・嚥下リハビリテーション。東京：南山堂 ; $2011,2-5$.

5）土岡寬和. 認知症高齢者のための舐攝機能検査法の開発. 広 大歯誌 $2014 ; 46: 23-35$.

6）藤島一郎。スクリーニングと精査，評価。與燕下障害ポケット マニュアル，第 3 版．東京：医歯薬出版；2012，37-62.

7) 苅安 誠。発声・構音器官の障害. 日本嚥下障害臨床研究 会，嚥下障害の臨床，第 2 版。東京 : 医歯薬出版；2008, $107-122$.

8）藤島一郎。訓練法のまとめ (2014 版), 日摂食・與下リ八会 誌 $2014 ； 18(1) ： 55-89$.

9）富田幸代, 中崎俊克, 角田正健ほか. 舌苔除去キャンディ開 発に関する研究. 日歯周誌 $2005 ; 46: 185$.

10）渋谷耕司, 鄭 英里, 宮原千春ほか. 要介護高齢者の口腔環 境に及ぼす棒付きキャンディーの影響. 日本老年歯科医学会 総会学術大会プログラム抄録集 $2009 ; 20 ： 147$.

11) Tsuga K, Maruyama M, Yoshikawa M, Yoshida M, Akagawa Y. Manometric evaluation of oral function with a hand-held balloon probe. J Oral Rehabil 2011; 38: 680-685.

12）田代晴基, 田村文誉, 平林正裕, 濱田 了, 米山武義, 菊谷 武. 新しい簡易口腔内細菌数測定装置の介護現場における臨床応 用. 障歯誌 $2012 ; 33: 85-89$.

13) Robbins J, Gangnon R.E, Theis S.M, Kays S.A, Hewitt A.L, Hind J.A. The Effects of Lingual Exercise on Swallowing in Older Adults. J Am Geriatr Soc 2005 ; 53 : 1483-1489.

14）浦部晶夫. 神経系に作用する薬剤. 島田和幸, 川合眞一, 今 日の治療薬 解説と便覧, 第 36 版. 東京 : 南江堂 ; 2014, 826.

15）原 修一, 三浦宏子, 山崎きょ子. 地域在住の 55 歳以上の住 民におけるオーラルディアドコキネシスの基準值の検討。日 老医誌 $2013 ； 50 ： 258-263$.

16) Utanohara Y, Hayashi R, Yoshikawa M. Standard values of maximum tongue pressure taken using newly developed disposable tongue pressure measurement device. Dysphagia $2008 ; 23: 286-290$.

17）岡田源太郎. 高齢者の唾液分泌改善を目指す新たな舌運動訓 練法の開発. 広大歯誌 $2009 ; 41: 33-43$.

18）石川正夫, 前田伸子, 渋谷耕司. 高齢者の口腔微生物に関す る研究 : 70 歳者の口腔状態と口腔微生物叢. 口腔衛生会誌 $2006 ; 56: 18-27$.

19）大屋朋子，多比良祐子，山根源之。地域連携 NST における 歯科衛生士の役割一歯科衛生士が中心的役割を担った一例一. 歯科学報 $2009 ； 109 ： 185-191$.

著者連絡先 : 山脇加奈子

干 731-5142 広島市佐伯区坪井 3-818-1

Tel: 082-923-8333

Fax: 082-923-7179

E-mail: dental_hygienist@pia-gr.or.jp 


\title{
Functional Oral Rehabilitation using Lollipop Candy for a Dysphagia Patient with Moderate Dementia
}

\author{
Kanako Yamawaki, DDSa , Mineka Yoshikawa, DDS, $\mathrm{PhD}^{\text {b }}$, Kazuhiro Tsuga, DDS, $\mathrm{PhD}^{\mathrm{b}}$ \\ Takayasu Kubo, DDS, $\mathrm{PhD}^{\mathrm{b}}$, Tsuyoshi Taji, DDS, $\mathrm{PhD}^{\mathrm{c}}$ and Yasumasa Akagawa, DDS, $\mathrm{PhD}^{\mathrm{d}}$ \\ ${ }^{a}$ Nakamura Geriatric Hospital \\ ${ }^{\mathrm{b}}$ Department of Advanced Prosthodontics, Applied Life Sciences, Institute of Biomedical and Health Sciences, \\ Hiroshima University \\ ${ }^{\mathrm{c}}$ Department of Oral Biology and Engineering, Integrated Health Sciences, Institute of Biomedical and Health Sciences, \\ Hiroshima University \\ ${ }^{\mathrm{d} O h u}$ University
}

Ann Jpn Prosthodont Soc 7: 179-184, 2015

\section{ABSTRACT}

Patient: A 73-year-old male with moderate cerebrovascular dementia was diagnosed as dysphagia by videofluoroscopic examination. A new exercise of sucking lollipop candy for about 15 minutes was added to his usual dysphagia rehabilitation for 6 months. Changes in swallowing and other oral function, number of bacteria on his tongue surface, body weight and diet condition were investigated during the rehabilitation period. After 6 months of intervention, tongue movement was improved, maximum voluntary tongue pressure, body weight and amount of diet was increased, while the amount of food residue of bolus and the number of oral bacteria were decreased.

Discussion: In addition to the usual rehabilitation, sucking lollipop candy could be applicable and effective for preventing deterioration of oral function and oral muscles due to disuse, in spite of insufficient understanding of the rehabilitation instructions due to moderate dementia.

Conclusion: Sucking lollipop exercise could be a prospective option which improves the oral environment in addition to oral function of dementia patients.

\section{Key words}

dementia, sucking function, lollipop candy, oral bacteria, oral function 